\title{
CAPACITY OF PLAINTIFF-STOCKHOLDER TO TERMINATE A STOCKHOLDER'S SUIT
}

\section{CHESTER B. MeLAUGHLIN†}

THE STOCKHOLDER's suit is a favorite device for transferring the burden of losses from the equity interest of a corporation to the management. In boom times, with dividends and stock market prices rising steadily, the management of a corporation could make its decisions without the restraint of critical scrutiny by litigious stockholders: stockholders then generally ignored the issues of managerial power involved in familiar schemes of expansion, and obediently forwarded their proxies for the annual meeting. During the lean years, however, punctuated as they have been with official publicity for the scandals of Frenzied Finance, stockholders have swarmed to the courts for recoupment of their losses.

The recent history of most corporations contains one or more occasions when managerial power was exercised with questionable wisdom. Properties have, for example, been acquired at far above a conservative valuation ; managements have conferred special privileges and bonuses upon themselves, or diverted some of the corporation's assets.

The injury resulting from such conduct is regarded as affecting only the corporation, ${ }^{1}$ which has a right of action against its officers for their breaches of duty and against any third parties privy to the transaction.' Although the stockholder may in fact be injured directly by the corporate loss, he is deemed not to have an individual right to recover damages for his losses from anybody ${ }^{2}$-unless the wrongdoer's breach of a duty to the corporation also breached a duty owed to the stockholder directly. ${ }^{3}$

infember of the New York Bar. The author wishes to achnowledge the assistance of William Mfertens, Ir., of the iNew York Bar, in the preparation of this article.

1. Kelly v. Dolan, 21S Fed. 966 (E. D. Pa. 1914), aff'd, 233 Fed. 635 (C. C. A. 3d, 1916) ; Whitten v. Dabney, 171 Cal. 621, 154 Pac. 312 (1915); Continental Securities v. Belmont, 206 N. Y. 7, 99 N. E. $13 S$ (1912).

- 2. Hodge v. Meyer, 252 Fed. 479 (C. C. A. 2d, 191S); Eldred v. Ripley, 97 Ill. App. 503 (1901) ; Converse v. United Shoe Mlachinery Co., 209 Mrass. 539, 95 N. E. 929 (1911); Bartlett v. New York, N. H. \& H. R. R, 221 11ass. 530, 109 NN. E. 452 (1915); Niles v. N. Y. Central \& H. R. R. R., 176 N. Y. 119, 6s N. E. 142 (1903); Hayden v. Perfection Cooler Co., 227 Mass. 5S9, 116 N. E. 871 (1917). See Glenn, The Stockholder's Stit-Corporate and Individual Grievances (1924) 33 Yale L. J. 580. In these cases, where there is only this indirect injury, the stocthbolder has no individual right of action, even though the wrongful acts may have been done with the design and malicious intent of injuring him. Wells v. Dane, $101 \mathrm{IFe} 67,63$ Atl. 324 (1905).

3. Ritchie v. MreMfullen, 79 Fed. 522 (C.C.A. 6th, 1S97); Mratter of Auditore, 249 N. Y. 335.164 N. E. 242 (1928); General Rubber Co. v. Benedict, 215 N. Y. 13, . 
Under suitable circumstances, however, the stockholder can assert a corporate right of action for the corporation, via the familiar pattern of the stockholder's suit, when the management's decision not to press for recovery on the corporate claim was not made in good faith as a matter of business judgment, but was shaped by what courts will call gross inattention to business, or disloyal sympathies with those who owed the corporation reparation. ${ }^{4}$ The stockholder's suit in general is based on this preliminary concept of a breach of trust by corporate officers towards the corporation as a whole in their failure to pursue a corporate claim. ${ }^{5}$

The stockholder is required substantially to exhaust his corporate remedies: that is, to make specific demand on the management that the action be prosecuted ${ }^{\mathfrak{c}}$ unless such demand would be futile, as when the board of directors is controlled by those whose acts are being impeached, ${ }^{7}$ or has already ratified the acts complained of. ${ }^{8}$ Having satisfied this requirement, the stockholder sues, representing all the stockholders, ${ }^{0}$ to enforce the corporate cause of action, joining the corporation as party defendant. ${ }^{10}$ The corporation is joined for two reasons: first to be a

109 N. E. 96 (1915) ; Stokes v. Continental Trust Co., 186 N. Y. 285, 78 N. E. 1090 (1906) (violation of plaintiff's pre-emptive rights); Comment (1929) 38 YALE L. J. 965.

4. See Kelly v. Dolan, 233 Fed. 635,638 (C. C. A. 3d, 1918); Whitten v. Dabney, . 171 Cal. 621, 154 Pac. 312 (1915); Byers v. Rollins, 13 Colo. 22, 21 Pac. 894 (1889); Pianten v. National Nassau Bank, 174 App. Div. 254, 259, 160 N.Y. Supp. 297, 302 (1st Dep't 1916), aff'd, 220 N. Y. 677, 116 N. E. 1070 (1917); See also Comment (1936) 45 YALE L. J. 649, 666; Glenn, op. cit. sippra note 2, at 588.

5. See Jones v. Missouri-Edison Electric Co., 144 Fed. 763, 771 (C. C. A. 8th, 1906); Ervin v. Oregon Ry. \& Navigation Co., 27 Fed. 625,630 (C. C. S. D. N. Y. 1886); Shaw v. Davis, 78 Mid. 308, 316, 28 Atl. 619, 621 (1894); RoHrtich, LAw and Practice of Corporate Control (1933) 99.

6. Bartlett v. N. Y. Central \& H. R. R. R., 221 Mass. 530, 109 N. E. 452 (1915). If the corporation is in receivership, the demand is to be made on the receiver. Kelly $v$. Dolan, 233 Fed. 635 (C. C. A. 3d, 1916).

7. Forbes v. Wilson, 243 Fed. 264 (N. D. Ohio 1917); Brewer v. Boston Theatre, 104 Mass. 378 (1870); Daniels v. Briggs, 279 Mass. 87, 180 N. E. 717 (1932); Glenn v. Kittanning Brewing Co., 259 Pa. 510, 103 Atl. 340 (1918).

8. Delaware \& Hudson Co. v. Albany, etc. R. R., 213 U. S. 435 (1909); Hawes v. Oakland, 104 U. S. 450 (1881); Continental Securities Co. v. Belmont, 206 N. Y. 7, 17,99 N. E. $13 S$ (1912); גircrea v. Robertson, 192 N. X. 150, 154, 84 N. E. 960 , 961 (1908); Byers v. Rollins, 13 Colo. 22, 21 Pac. 894 (1889).

9. Zinn v. Baxter, 65 Ohio St. 341,62 N. E. 327 (1901); Glenn, supra note 2, at 583 .

10. Davenport v. Dows, 18 Wail. 626 (U. S. 1873) ; Corey v. Independent Ice Co., 226 Mass. 391, 115 N. E. 488 (1917); Greaves v. Gouge, 69 N. Y. 154 (1877); Security Trust Co. v. Pritchard, 201 App. Div. 142, 194 N. Y. Supp. 486 (4th Dep't 1922) ; Kelly v. Thomas, $234 \mathrm{~Pa} .419,83$ Atl. 307 (1912). In England, a realistic view of the situation is taken and the corporation joined as party plaintiff. Duckett v. Grover, 6 Ch. D. 82 (1877). 
party to the suit, so that recovery can run in its favor, and so that it may be bound by the adjudication; ${ }^{11}$ and secondly to satisfy the underlying feeling that the stockholder's suit contains two causes of action: one by minority stockholders against the corporation for a breach of duty in failing, through its management, to prosecute a corporate right, and another, the corporation's cause of action against third persons, which can be considered only if the stockholder prevails in the first. ${ }^{12}$

The stockholder's suit is thus a derivative action, for the plaintiffstockholder is attempting to enforce a cause of action belonging wholly to another party and does not stand to gain individually by a favorable judgment: ${ }^{13}$ he has merely "derived" the right to sue by virtue of being a stockholder and any recovery accrues to the corporation. ${ }^{14}$ The action is also representative in that it is brought on behalf of a "class,"-the other stockholders, but it is not to be confused with other types of representative actions in which the plaintiff has a personal claim at issue and will profit directly from a favorable judgment. ${ }^{15}$

The stockholder's suit is commonly used as a check on the managerial discretion of corporate directors, and a means of restoring the value of corporate holdings when there is a difference in interest between management and equity-holders, or between minority and majority. Although it is an erratic instrument for achieving these ends, it is the most effective one available, and is therefore frequently employed. ${ }^{16}$ One of the important legal problems recurringly presented by its use centers around the status of the plaintiff-stockholder: what degree of

11. Davenport v. Dows, 18 Wall. 626 (U. S. 1873) ; Landis v. Sea Isle City Hotel Co., 53 N. J. Eq. 654, 33 Atl. 964 (1S96); (1934) 44 Y YLE L. J. 1091.

12. See Cantor v. Sachs, 162 Atl. 73, 76. (Del. Ch. 1932); Batraritnie, Minutunt of Corporation Law and Practice (1930) \$186.

13. Cf. Dickinson y. Consolidated Traction Co., 114 Fed. 232, 239 (C. C. D. N. J. 1902); Dana v. Morgan, 232 Fed. 85, 90 (C. C. A. 2d, 1916); 13 Fletcher, Cyczopedrs of the Law of Private Corforations (1931) \$5939.

14. Davis v. Peabody, 170 Mass. 397, 49 N. E. 750 (1S93); Landis v. Sen Isle City Hotel Co., 53 N. J. Eq. 654, 33 Atl. 694 (1S95); Zinn v. Baxter, 65 Ohio St. 341, 62 N. E. 327 (1901); Glenn, op. cit. sinpra note 2, at 550.

15. See Comment (1934) 34 CoL. L. REv. 11S, 119 and cases there cited A gersonal claim of the stockholder-plaintiff generally cannot be asserted in conjunction with the corporate claim before the court in the derivative action. Brock v. Poor, 216 N. Y. 387, 111 N. E. 229 (1915) ; cf. Brinckerhoff v. Bostwick, 99 N. Y. 185, 1 N. E. 663 (18s5).

The most common representative actions in which plaintiff and the "class" membars have a personal claim at issue are those by creditors as for appointment of a receiver for their debtor [Union Trust Co. v. Jones, 16 F. (2d) 236 (C. C. A. Gth, 1926).], or to set aside a fraudulent conveyance [Stewart v. Dunham, 115 U.S. 61 (1SS5)], or to enforce stockholders' statutory. liability [Hirschfeld v. Fitzgerald, 157 N. Y. 165, 51 N.E. 997 (1898)]. 190.

16. See Simpson, Fifty Years of American Equily (1936) 50 FLarv. L. REv. 171, 
control is he permitted over the action he has instituted? And what effect can his conduct of the suit have on the corporate right?

There is no doubt that a final judgment in a derivative suit ${ }^{17}$ (as well as in one where the plaintiff suing on behalf of a class also has a personal claim at issue ${ }^{18}$ is res judicata and bars other stockholders from pursuing the same corporate cause of action, in the absence of fraud or collusion. ${ }^{10}$ But there is no simple formula which describes the permissible extent of the plaintiff's control over the suit prior to the rendition of final judgment.

In the first place, what is the effect of the commencement of the action on the corresponding rights of the other stockholders? Is the plaintiff constituted the sole representative of the class by his decision to litigate the corporate right, in that no other stockholder may commence a similar action while his is pending? 'Prior to the institution of suit, all stockholders share the same privilege to bring an action on behalf of the corporation; ; ${ }^{20}$ but, when the machinery of suit on behalf of the corporation has been set in motion by one stockholder, the privileges of the others to do likewise may be viewed as suspended. ${ }^{21}$ The equitable purposes, for which the stockholder's privilege to sue is recognized, have been temporarily satisfied. Since bringing a suit by one stockholder merely suspends and does not extinguish the privileges of other stockholders to sue, if the suit is discontinued by the plaintiff stockholder, the rights of other stockholders to commence action on behalf of the corporation are revived. Considering the institution of an action by one stockholder as a temporary bar to another suit can, it appears,

17. Dana v. Morgan, 232 Fed. 85 (C. C. A. 2d, 1916); Alesander v. Donohuc, 143 N. Y. 203, 38 N. E. 263 (1894) ; Hochman y. Mortgage Finance Corp., 289 Pa. 260, 137 Atl. 252 (1927); Fahrenwald v. Spokane Savings Bank, 179 Wash. 61, 35 P. (2d) 1117 (1934) ; RoERLICE, op. cit. stpra note 5, at 166.

18. Kerr v. Blodgett, 48 N. Y. 62 (1871); Hirschfeld v. Fitzgerald, 157 N. Y. 166, 51 N. E. 997 (1898); Piedmont Life Insurance Co. v. Maury, 75 Va. 508 (1881),

19. Beers v. Denver \& R. G. W. R. R., 286 Fed. 886 (C. C. A. 8th, 1923); Willoughby v. Chicago Junction Ry., 50 N. J. Eq. 656, 25 Atl. 277 (1892); see Gerith Realty Co. v. Normandie National Securities Corp., 154 Misc. 615, 276 N. Y. Supp. 655 (Sup. Ct. 1933), aff'd, 241 App. Div. 717, 269 N. Y. Supp. 1007 (1st Dep't 1934), aff'd, 266 N. Y. 525,199 N. E. 518 (1935).

20. Whitten v. Dabney, 171 Cal. 621, 154 Pac. 312 (1915); Gerith Realty Corp. v. Normandie National Securities Corp.; 154 Misc. 615, 276 N. Y. Supp. 655 (Sup. Ct. 1933), aff'd, 241 App. Div. 717, 269 N. Y. Supp. 1007 (1st Dep't 1934), aff'd, 266 N. Y. 525, 199 N. E. 518 (1935) ; Dresdner v. Goldman Sachs Trading Corp. 240 App. Div. 242, 269 N. Y. Supp. 360 (2nd Dep't 1934), leave to appeal denied, 241 App. Div. 745, 270 N. Y. Supp. 961 (2nd Dep't 1934).

21. Goodbody v. Delaney, 80 N. J. Eq. 417, 419, 83 Atl. 988 (1912). But see Brinckerhoff v. Bostwick, 99 N. Y. 185, 196, 1 N. E. 663, 668 (1885). Cf. 13 Fletcher, op. cit. sttpra note 13 , at $\$ 6019$, n. 83 . 
work no injustice to the would-be plaintiff-stockholder. He can always intervene and be joined as a party plaintiff in the original action, thus gaining an equal voice with the original plaintiff in its conduct. ${ }^{22}$ In the absence of collusion, the right of the corporation is before the court in a stockholder's suit just as completely as if the corporation itself had instituted the proceeding; if in the same tribunal a second stockholder's action is commenced, duplicate litigation of the same claim results, so that the defendant would seem entitled to a dismissal as of right on the ground of another action pending. ${ }^{23}$

Nevertheless the New York Appellate Division has recently supported the contrary view that dismissal under these circumstances is a matter of discretion for the court trying the second stockholder's suit. In that case a stockholder had brought action on behalf of a corporation against its directors, alleging mismanagement and dissipation of corporate assets. Another stockholder's action was already awaiting trial on the identical issues, and the defendants made a motion to dismiss the new action as of right. The court took the position that inasmuch as each stockholder had an inherent right to sue, independent of any other stockholder's right to sue, the bringing of suit by one had no automatic effect upon the rights of the others; and the court claimed discretion either to allow the two suits to continue separately or to dismiss the secondd one depending on whether undue multiplicity was involved."s

The court justified its refusal to make the institution of one stockholder's action a bar, even though merely temporary, to the commencement of any other, on the ground that otherwise "the door is open to collusive actions." Ability to intervene and revival of the right of other stockholders to sue if the present plaintiff failed to prosecute the action to judgment were dismissed as insufficient safeguards. "He

22. See MrcAlpin v. Universal Tobacco Co., 57 Atl. 413 (N. J. Eq. 1904); Goodbody v. Delaney, SO N. J. Eq. 417, 420, 83 Atl. 985,989 (1912); Grant v. Greene Consolidated Copper Co., 169 App. Div. 206, 212, 154 N. Y. Supp. 596, 601 (1st Dep't 1915), aff'd, 223 N.Y. 655, 119 N.E. 1046 (191S); Gerith v. Normandie National Securities Corp., 154 Mlisc. 615, 276 N. Y. Supp. 655 (Sup. Ct 1933), aff'd, 241 App. Div. 717, 269 N. Y. Supp. 1007 (1st Dep't 1934), aff'd, 266 N. Y. 525, 199 N.E. 513 (1935); cf. Southern Pacific R. R. v. Bogert, 250 U.S. 483, 490 (1919).

23. See Aipert v. Mercury Publishing Co., 272 Mass. 39, 41, 172 N. E. 221, 222 (1930) ; Goodbody v. Delaney, SO N. J. Eq. 417, 419, \&3 Atl. 983 (1912); cf. Gerith Realty Corp. v. Normandie National Securities Corp. 154 Mfisc. 615, 276 N. Y. Supp. 655 (Sup. Ct. 1933), aff'd, 241 App. Div. 717, 269 N. Y. Supp. 1007 (1st Dep't 1934), $a f^{\prime} d, 266$ N. Y. 525, 199 NT. E. $51 \mathrm{~S}$ (1935). But of. Dresdner v. Goldman Sachs Trading Corp., 240 App. Div. 242, 269 N. Y. Supp. 360 (2nd Dep't 1934), lecov to oppeal denicd, 241 App. Div. 745, 269 N. Y. Supp. 1007 (2nd Dep't 1934).

24. Dresdner v. Goldman Sachs Trading Corp., 240 App. Div. 242, 269 N. Y. Supp. 360 (2nd Dep't 1934), leave to appeal denied, 241 App. Div. 745, 269 N. Y. Supp. 1007 (2nd Dep't 1934). 
(plaintiff) may omit from his complaint material allegations which have been discovered by another more vigilant and industrious . . . There is nothing to prevent defendants, before judgment, from buying their peace with the plaintiffs by means of a private settlement, leaving other stockholders to seek their remedy by a new action, if the statute of limitations has not run against them . . There is no requirement that the stockholder who sues or the defendants shall give notice of the suit to other stockholders . . . It would be very easy for offending officers and directors to obtain a friendly stockholder to begin an action and to suppress all information on the subject." 25

However, if the plaintiff-stockholder will be effectively prevented from conducting the suit so as materially to. prejudice the corporate claim, then there would be little basis in fact for the New York court's denial that the institution of one stockholder's suit should temporarily bar another, a ruling which fails to protect defendants against a multiplicity of actions. If, on the other hand, it is not possible to insure adequate presentation of the corporate claim in the stockholder's action, the reasons advanced by the Appellate Division in support of its position seem persuasively to justify its view that the beginning of one derivative suit does not suspend the power of other stockholders to do likewise.

Generally speaking a stockholder-plaintiff can prejudice the cause of action in two ways: one by discontinuing the suit, and second by compromising the suit and obtaining the entry of a consent judgment. The discontinuance may result in the surrender of an advantage already gained in the litigation, or even if ostensibly effected without prejudice may subject the cause of action to the statute of limitations. Compromising a suit and entering a consent judgment, in the absence of a showing of fraud or collusion, destroys a right of action. ${ }^{20}$

It is, however, hardly desirable as a matter of policy to force every stockholder's action to be carried through to judgment. Like other litigation, the stockholders' suit is an expensive luxury, especially for the stockholder-plaintiff who cannot recover direct personal benefit from the action and is even unable to obtain reimbursement for costs from the corporation unless a favorable judgment is obtained. ${ }^{27}$ Since stockholders already are aware that they have everything to lose and nothing to gain, if there is added to this a requirement that an action once commenced must always be prosecuted to final judgment, resort to the stock-

25. Id. at 247,269 N. Y. Supp. at 367 .

26. See p. 430 infra. Cf. RonrLrch, op. cit. supra note 5 , at 167.

27. Decatur Mineral \& Land Co. v. Palm, 113 Ala. 531, 21 So. 315 (1896); Greenough v. Coeur D'Alenes Lead Co., 52 Idaho 599, 18 P. (2d) 288 (1933); Forrester v. Boston and Maine Consolidated Copper and Silver Mining Co., 29 Mont. 397, 74 Pac. 1088 (1904); Fitzgerald v. Bass, 122 Okla. 140, 252 Pac. 54 (1927). 
holder's suit may well be discouraged, a result to be avoided in view of the utility of the action as the main instrument available to an oppressed minority for curbing otherwise unlimited managerial power and for recouping corporate losses.

Two fact situations are commonly distinguished: one where the corporation acquiesces to the proposed discontinuance or settlement, and second where the corporation opposes such action. It may be suggested that, inasmuch as the right of action is that of the corporation, the stockholder's power to discontinue or compromise the action is dependent upon such consent. The materiality of the presence or absence of corporate consent is, however, questionable, regardless of whether or not the dismissal will prejudice the corporate cause of action; it is doubtful whether any weight should be given it at all. Since if is an integral part of the stockholder's case that the corporation's decision not to prosecute the action was a breach of duty, manifestly corporate consent to a dismissal of the bill, an empty repetition of its allegedly wrongful opinion, is no assurance that corporate interests will not be prejudiced by a dismissal. When dismissal will not prejudice the corporate right of action a stockholder may be allowed a discontinuance regardless of the corporation's views, in the absence, of course, of any intervention by fellow stockholders. ${ }^{23}$ Possibly, this privilege is clearer where the corporation consents. But even in the absence of corporate consent, allowing the stockholder to discontinue ${ }^{29}$ in such cases imposes no burden on the corporation or on other stockholders. It should be recalled that the stockholder must prosecute the action at his own expense and without hope of reimbursement from the corporation unless successful. It seems unnecessarily harsh to force him to continue the action even when no material harm can be done by a discontinuance and even though he may no longer be able to finance the action or has become convinced that it is unfounded. There is, moreover, no reason to allow the corporation which has refused to bring the suit itself to compel the continuance of the action at the expense of a presumably innocent stockholder by withholding its consent for a dismissal.

28. Witousek v. Ideal Yeast Co., 194 Iowa 47, 1SS N. W. 772 (1922); Bernheim v. Wallace, 186 Ky. 459, 217 S. W. 916 (1926); Dresdner v. Goldman Sachs Trading Corp., 240 App. Div. 242, 269 N. Y. Supp. 360 (2nd Dep't 1934), leare to appeal denicd, 241 App. Div, 745, 270 N.Y. Supp. 961 (2nd Dep't 1934); Grant v. Consolidated Copper Co., 169 App. Div. 206, 154 N. Y. Supp. 596 (Ist Dep't 1915), aff'd, 223 N. Y. 655, 119 N. E. 1046 (1918). See also as adopting the doctrine cited in the tert, 4 Coor, Corporations (Sth ed. 1923) 3286; 13 Fletcher, Cycropedin of Corporntroits (1931) \$6019. Cositra: Whitten v. Dabney, 171 Cal. 621, 154 Pac 312 (1915).

29. Witousek v. Ideal Yeast Co., 194 Iowa 47, 188 N. W. 772 (1922); cf. Bezdleston v. Alley, 55 Hun 606, 7 N. Y. Supp. 747 (App. Div. 2d Dep't 18s9), appcal dismisscd, 119 N. Y. 659,23 N. E. 1150 (1890). 
When the proposed action of the stockholder will materially prejudice the corporation's underlying right of action, as by surrendering an advantage already gained in the litigation, or subjecting the cause of action to the statute of limitations, ${ }^{30}$ the stockholder's privilege of dismissal is not so unambiguous, although again the assent of the corporation to the dismissal seems immaterial. To allow the plaintiff stockholder an unrestricted privilege of dismissal under such circumstances would make a simple technique available to fraudulent directors whereby they could exploit the corporation, and protect themselves against any possibility of future liability, by having a compliant stockholder sue obscurely, and withdraw at an appropriate time to block any further action with a plea of the statute of limitations. ${ }^{31}$

30. For a fact situation in which the statute of limitations will apparently bar further action after the stockholder-plaintiff has discontinued a stockholder's suit, see Beadleston v. Alley, 55 Hun 606, 7 N.Y. Supp. 747 (App. Div. $2 d$ Dep't 1889), appeal dismissed, 119 N. Y. 659, 23 N. E. 1150 (1890). Generally a stockholder cannot bring a derivative action on the corporate claim after the statute of limitations has run on it. Kelly v. Dolan, 233 Fed. 635 (C. C. A. 3d, 1916) ; Brinckerhoff v. Bostwick, 98 N. Y. 185, 1 N. E. 663 (1885); Wallace v. Lincoln Savings'Bank, 89 Tenn. 630, 15 S. W. 448 (1891); of. Backus-Brooks Co. v. Northern Pacific Ry., 21 F. (2d) 4 (C. C. A. 8th, 1927); see Wallace v. Lincoln Savings Bank, 89 Tenn. 630, $15 \mathrm{~S}$.W. 448,453 (1891). On occasion, however, courts confusedly overlook the character of the stockhoider's action and talk of the statute of limitations as running against him so as to bar his power to bring the action, implying that the statute commences to run from the date that the stockholder first learns of the corporate claim. $C f$. Fleming v. Black Warrior Copper Co. Amalgamated, 15 Ariz. 1, 136 Pac. 273 (1913). This would appear an unfounded position. True, the action is based in part on breach of trust or fraud and as to this, the statute might conceivably be said to Iun from the date. of the acquisition of knowledge by the stockholder-plaintiff. See p. 422, supra. However, it is fraud or breach of trust on the part of the corporate management and the attempt now is not to bar action against the corporation for its breach of trust or fraud, but to prevent any recovery from the party against whom the corporate right lay. The entire action hinges upon that corporate right and if it no longer exists then, clearly, the stockholder can derive no right from the corpora- . tion on which to bring the action. See FlETCHER, op. cit. sitpra note 13 , at $\$ 5886$.

Since holding that the running of the statute on the corporate claim bars'a derivative action may easily result in hardship, it is generally qualified in two important respects, in "extraordinary" cases, where there are unusually strong equities in favor of the complainant: (1) If the transaction giving rise to the corporate cause of action was hidden from the stockholders so that they could not obtain knowledge of it, their power to bring a derivative action is not destroyed by the running of the statute of limitations as to the corporate right Backus-Brooks Co. v. Northern Pacific Ry., 21 F. (2d) 4, 12 (C. C. A. 8th, 1927); Wallace v. Lincoln Savings Bank, 89 Tenn. 630,15 S.W. 448,453 (1891); (2) While the corporation is under the control of those against whom the claim lies, the statute does not commence to run until this control is terminated. Whitten v. Dabney, 171 Cal. 621, 154 Pac. 312 (1915); Reich v. Robinson, 64 Cal. App. 46, 220 Pac. 676 (1923).

31. Even though the corporate claim may not be barred by the statute of limitations, yet an individual stockholder may be unable to bring a derivative action on it 
Where a representative plaintiff has a personal claim at issue, he may not as of right discontinue his action after the granting of an order or decree affecting the rights of other members of the class. The entry of an interlocutory judgment, ${ }^{32}$ or the appointment of a receiver, ${ }^{33}$ for example, may enable other creditors to prevent a discontinuance, even though they were not original parties to the action. There is more reason for denying a derivative plaintiff this power of discontinuance than for withholding it from a representative plaintiff who has, an individual claim at stake. The possible hardship in requiring the stockholder to continue the litigation which he has voluntarily instituted should not induce the court to permit him to impair the corporate cause of action. Several courts, however, have said otherwise. Thus in the recent Dresdner case the court remarked, although its decision turned on another point, that in a derivative action the plaintiff may discontinue even where such discontinuance is fatal to an advantage gained.9 And in an old New York case, plaintiff-stockholder was induced to withdraw the suit in consideration of a personal payment after trial but before the entry of judgment. The receiver of the corporation and other stockholders sought to oppose it. Yet the court said, "The plaintiff had the right to settle her own grievance against the parties who had done her the alleged wrong; and it was none of the other stockholders' business how or by what means she did it." ${ }^{35}$ It will be observed that

because of his laches, generally arising from unreasonable delay in bringing suit after acquiring knowledge of the existence of the claim. FLETCHER, op. cit. sipre note 13 , at $\$ 5874$ and cases there cited. Of course, the laches of one stockholder does not bar suit by others not similarly situated. However, by commencing an obscure action, then discontinuing it ostensibly without prejudice, it may be possible to taint all stocltholders with laches. The bringing of the first action may be said to be sufficient notice for the purpose of giving all stockholders constructive knowledge of the existence of a corporate right which is not being enforced. Cf. Taylor v. South \& North Alabams R. R, 13 Fed. 152 (C.C.M.D. Ala. 1SS1); Williamson Croit Hat \& Notion Co., \$2 W. Va. 549, 96 S. E. 929 (1918); Gils v. Elizabeth Lalke Corporation, 250 sfich. 443, 220 N. W. 509 .(1930). Failure to bring a new action reasonably soon after the discontinuance of the first action may be viewed as laches; however, no case discussing or considering this point has been found, although some possibility of a holding to that effect is indicated in Brinckerhoff v. Bostwick, 99 N.Y. 1S5, 1 N. E. 663, 658 (1S85).

32. Salisbury v. Binghamton Publishing Co., $\$ 5$ Hun 99, 32 N. Y. Supp. 652 (App. Div. 4th Dep't 1895). But of. In te Alpha Co. Ltd. [1903] I Ch. 203.

33. Belmont NTail Co. v. Columbia Iron \& Steel Co., 46 Fed. 336 (W. D. Pa. 1S91).

34. Dresdner v. Goldman Sachs Trading Corp., 240 App. Div. 242, 269 N. Y. Supp. 360 (2nd Dep't 1934), lecoe to appeal denied, 241 App. Div. 745, 270 N. Y. Supp. 961 (2nd Dep't 1934).

35. Beadleston v. Alley, 55 Eun 606, 7 N. Y. Supp. 747 (App. Div. 2nd Dep't 1859), appeal dismissed, 119 N. Y. 659, 23 N. E. 1150 (1S90). 
the court here entirely overlooked the fact that the action had been brought on behalf of the corporation and that no actionable injury had been inflicted upon the plaintiff; it is difficult to understand what interest of her own was involved to give the plaintiff an "absolute right" to settle the derivative suit, after she had obtained a favorable decision, especially in the face of strong objection by the representative of her corporate principal.

The equities against allowing the stockholder-plaintiff to prejudice the derivative right of action should be even clearer when it is proposed that the action be settled and a consent judgment be entered. In the absence of a showing of fraud or collusion the compromise and the entry of a consent judgment generally destroys a right of action, ${ }^{30}$ and fraud or collusion are exceedingly difficult to prove. To allow a single stockholder or group of stockholders the power to make a private compromise of the corporate cause of action places a heavy reliance upon their judgment (assuming its exercise in good faith), and leaves the corporate claim (and the indirect rights of non-joining stockholders) at the mercy of individuals who have no hope of personal recovery even if the suit is prosecuted successfully, and who stand to suffer considerable losses in costs if unsuccessful; obviously a wide door is opened to strike suits and collusive payments to stockholders which may rarely, if ever, be recovered by the corporation. ${ }^{37}$

Nevertheless the power of a stockholder to compromise the derivative suit has apparently been recognized. Statements are often found to the effect that

"It is a principle of equity practice, when a person brings a suit in behalf of himself and such others as may wish to come in who are similarly. situated, that the complaining stockholder controls the case and may continue, compromise, abandon, or discontinue it at his pleasure." 38

But such generalizations seem woefully insecure when examined in terms of the cases in which they appear. Not only do the facts of cases fail to support the dicta, but the courts often confuse the author-

36. Cf. Cutter v. Arlington Casket Co., 255 Mass. 52, 151 N. E. 167 (1926); Gerith v. Normandie National Securities Corp., 154 Misc. 615, 276 N. Y. Supp. 655 (Sup. Ct. 1933), aff'd, 241 App. Div. 717, 269 N. Y. Supp. 1007 (1st Dep't 1934) aff'd, 266 N.Y. 525, 199 N.E. 518 (1935); RoHRLick, op. cit. supra note 5, at 167.

37. No cases directly in point appear to exist, but analogies supporting such recovery may perhaps be found in cases allowing recovery by a principal or employer of sums secretly paid to and received by an agent. Cf. Donemar, Inc. v. Mallory, 252 N. Y. 360, 169 N. E. 610 (1930) ; Boston Deep Sea Fishing \& Ice Co. v. Ansell, 34 Ch. Div. 39 (1888).

38. 4 Cook, Corporations (8th ed. 1923) 3286. 
ities which are listed to justify their conclusion. They ignore the distinction between a derivative suit and other representative actions in which the plaintiff has a personal claim at issue, a distinction of considerable relevance to the stockholder's power to compromise stockholders' suits. They cite cases in which discontinuance without prejudice has been allowed, as authority to support a compromise or prejudicial discontinuance, problems which are of course completely different, and which involve a consideration of the scope which should be given as a matter of equity policy to the stockholder's capacity to influence a corporate interest.

Certain cases are recurringly cited in support of the proposition that a derivative plaintiff has the power to effect a binding compromise of the cause of action. Most of them, curiously, are from New York. At the outset, in New York, the judicial remarks on the right to compromise were properly restricted to a settlement by a representative plaintiff who had an individual right at issue of his own claim. Thus, in an early action of that character, the Chancellor said, "In cases of this kind it is competent for the complainant to settle with the defendants, and to withdraw his suit, without the consent of the other creditors, at any time before decree." 39 Subsequently in the leading case of Brinckerhoff $v$. Bosizick, the Court of Appeals said sweepingly, "It is true, that at any time before judgment, the original plaintiff, before the others were made parties, could have discontinued the suit or could have settled his individual damages with the defendants, and have executed a release which would have been effectual as to him."10 This case has frequently been cited as an authority to support the proposition that a derivative plaintiff may settle the suit, without reference to the fact that there the plaintiff placed in issue both a derivative right and an individual claim as a member of a wronged class, ${ }^{41}$ and that the court, in making the generalization, was undoubtedly discussing the latter claim, for it speaks of the plaintiff as settling "individual damages"; of course, a derivative plaintiff has no individual damage to settle. Moreover, the court's remarks as to the degree of control possessed by plaintiff stockholder over the derivative action was entirely dicta since the only point at issue concerned the running of the statute of limitations as to intervening stockholders.

Brinckerhoff v. Bostwick was followed in Hirshfeld v. Fitzgerald, 2 case in which plaintiff representing other creditors of a closed bank sought

39. Innes v. Lansing, 7 Paige 5S3, 585 (N. Y. Ch. 1839).

40. 99 N. Y. 1S5, 194, 1 N. E. 663 (1SS5).

41. This becomes especially clear from a study of reports of the same litigation at earlier stages. See $S S$ N. Y. 52 (1SS2) and 34 Hun 352 (App. Div. 2nd Dep't, 18S4).

42. 157 N. Y. 166, 51 N. E. 997 (1898). 
to enforce stockholder's statutory liability, and thus to attain a personal benefit. Although no question of a derivative suit was before the court in that case, it is nevertheless cited both in New York and other jurisdictions as an authority in connection with derivative suits, and especially the power to compromise them. ${ }^{43}$ Thus, at a later date, in what was in fact a derivative suit the court, after describing the "stockholder's suit" as a "representative action" and failing to distinguish it from other representative suits in which the plaintiff is litigating a personal claim, states that the plaintiff "has the right to control the action or to compromise or discontinue it at pleasure," and cites as controlling Brinckerhoff $v$. Bosiwick and Hirshfeld $v$. Fitzgerald.4

The situation in New York is typical: there is a wealth of dicta in terms broad enough to uphold the power of a plaintiff-stockholder to settle the corporate (derivative) cause of action, but no decision squarely supports the proposition. In fact, no decision directly upholding the existence of such a power has been found in any other jurisdiction; and it has in several jurisdictions been flatly determined that a derivative plaintiff has not the power to settle a corporate controversy, at least without the consent of the court. ${ }^{45}$

This result is clearly sound; important reasons of corporate and judicial policy support a denial to stockholder-plaintiffs of unrestricted power to dispose of corporate claims. But it seems necessary to avoid a rule which would force the stockholder to prosecute every derivative action to final judgment: He may discontinue if he can avoid prejudicing the corporate right. But such discontinuance is impractical; compromise and settlement is more often to be preferred, especially from the standpoint of economy in litigation, but only, however, if there is some assurance that the compromise is adequate and fair.

Three possible courses suggest themselves as tending to make possible the achievement of both objectives:

1. It can be required that the proposed settlement be submitted to all stockholders for unanimous consent. But the necessity for unanimous

43. See e. g., Johnson v. King, Richardson Co., 36 F. (2d) 675 (C. C. A. 1st, 1930); Bernheim v. Wallace, 186 Ky. 459, 217 S. W. 916 (1920); Goodbody v. Delancy, 80 N. J. Eq. 417, 83 At1. 988 (1912). Similarly in textbooks, sec Cook, op. cit. silpra note 38 , at 3286 .

44. Grant v. Greene Consolidated Copper Co., 169 App. Div. 206, 154 N. Y. Supp. 596 (1st Dep't 1915), aff'd, 223 N. Y. 655, 119 N. E. 1046 (1918).

45. Whitten v. Dabney, 171 Cal. 621, 154 Pac. 312 (1915) ; Beaudette v. Graham, 267 Mass. 7, 165 N. E. 671 (1929) ; cf. Cutter v. Arlington Casket Co., 255 Mass. 52, 151 .N. E. 167 (1926); Gerith v. Normandie National Securities Corp., 154 Misc. 615, 276 N. Y. Supp. 655 (Sup. Ct. 1933), aff'd, 241 App. Div. 717, 269 N. Y. Supp. 1007 (1st Dep't 1934), aff'd, 266 N. Y. 525, 199 N. E. 518 (1935). See also Comment (1934) 34 Cós. I. Rev. 118, 126. 
consent, particularly where the corporation has many stockholders, raises a practical obstacle which would be almost insurmountable. Further, this plan would vest in a single stockholder an unconscionable and potentially expensive veto power.

2. The requirement may be merely for approval of the submitted plan by a majority vote at a meeting of stockholders. Presumably, however, a majority of the stock is controlled by, or is at least friendly to, the defendant directors, since a majority vote has placed and retained them in office. A vote of a majority of all the stockholders in favor of the settlement, therefore, would be not much more effective in insuring an equitable compromise than a vote of the directors themselves. On the other hand, if the stock owned or controlled by the defendant directors were disqualified, the action of the corporation in respect-to the settlement would often be determined by a minority of its stockholders who, being opposed to the management, would probably disapprove of the plan regardless of its merits. This would be unfair not only to the majority stockholders but to the corporation itself, as the proposed settlement might well be beneficial to it.

3. Finally, the approval of the proposed settlement might be left to the discretion of the court. This method of settlement is the most practical. There seems to be no reason to doubt that the consent decree thus entered would be binding on all stockholders; ${ }^{40}$ so long as a final judgment after trial obtained by a stockholder in a derivative suit binds all other stockholders on the principle of res adjudicata, no reason appears why a consent decree should not in a like manner be effective to adjudicate conclusively the cause of action when, of course, the settlement is paid to the corporation. ${ }^{47}$ Because of the court supervision over the compromise, no valid reason exists why we should here have an exception to the otherwise generally binding effect of consent judgments. That in a non-derivative suit all parties enter into a compromise uninfluenced by factors other than the merits of the compromise, whereas in a derivative action, there is the probability that one of the parties, the corporation, is dominated by the defendants is offset by the added element of judicial supervision. For, two courses of action are open to the court, either of which insure adequate protection of all the interests involved. It may inquire and decide whether, in proposing to enter into the compromise for the corporation, the directors are acting oppressively or fraudulently, or as proper corporate representatives without self-interest. And if the latter be determined, the court need inquire no further into the merits of the settlement; the corporation is then as

46. See notes 36 and 44 , supra.

47. See Harding v. Harding, 198 U. S. 317 (1905); FreEarast, Jodgarerits (5th ed. 1925) 2774 and cases there cited. 
free to act as if it had been the original plaintiff. If, however, the court has doubts as to the openmindedness of the directors, it may disregard entirely the assent of the corporation, and, after examining all the circumstances, reach an independent decision on the fairness of the settlement.

Three cases have been found which utilize or suggest this technique. In Whitten $v$. Dabney, ${ }^{48}$ a derivative suit was settled privately without the court's approval. The court held that the position of the stockholder plaintiff was that of a trustee for the corporation and that, as such, he was required to submit the proposed settlement to the court, whose duty it was to pass upon its fairness. Likewise in Bernheim v. Wallace, ${ }^{40} \mathrm{a}$ stockholder's suit was settled privately and a decree entered by consent, which purported to be without prejudice to certain of the corporate rights. The appellate court reversed the decision of the lower court which had refused to recognize the settlement. It is true that although there was here an agreed judgment with respect to certain matters, it purported to be without prejudice as to others. The case is important, however, because the appellate court based its decision on the merits of the settlement and upon its determination that the compromise. was fair and equitable; because the court approved of the agreed judgment, even though the corporation thereby surrendered valuable advantages previously gained in the trial of the action; and because the case is a holding to the effect that a stockholder who was not a party to the suit and who now sought to assert a derivative claim, was bound by the settlement.

Gerith Realty Corporation v. Normandie National Securities Corporttion raised the question under consideration squarely. In a stockholder's derivative suit, a settlement was agreed upon between the plaintiff and the defendant directors and was submitted to the court for its approval. The court directed that a meeting of stockholders be held in the courtroom, at which, by a majority vote, the settlement was approved, and after the court had taken "the utmost pains to prevent an ill advised settlement," judgment by consent was entered. A new suit was subsequently commenced on the corporate cause of action by a stockholder who had voted against the original settlement and by another who had not been at the meeting. The court held that regardless of whether a notice of the proposed settlement was given to all stockholders, "the judgment in the absence of collusion or other fact showing it was fraudulent is binding on the corporation and, incidentally, on each agent who has the capacity to sue in the right of the corporation." This decision was affirmed without opinion by the Appellate Division of a

48. 171 Cal. 621, 154 Pac. 312 (1915).

49. 186 Ky. 459,217 S. W. 916 (1920). 
different Department from that in which the Dresdner case was decided, and by the Court of Appeals. ${ }^{50}$

"Discretion of the court" is all too frequently the solution proposed sor a difficult problem. But in a stockholder's derivative suit, we have an unusual difficulty; the good faith of all parties before the court is uncertain. Judicial supervision appears to be the best possible means of protecting the rights of other stockholders and creditors, absent parties with definite and substantial interests at stake. True, when a proposed compromise is laid before the court, it is in effect being asked to make a finding on the merits of the stockholder's claim without the thorough investigation of facts supposed to characterize trials. But some legal mechanism for compromising a derivative action must be provided; it seems preferable with so many interests at stake, to give final discretion to the court rather than to remit the parties solely to their own judgment and to rely entirely upon their good faith.

50. 154 Mfisc. 615, 276 N. Y. Supp. 655 (Sup. Ct 1933), aff'd, 241 App. Div. 717, 269 N. Y. Supp. 1007 (1st Dep't 1934), aff'd, 266 N. Y. 525, 199 N. E. 518 (1935). 